\title{
PERENCANAAN DAN UJI PERFORMA ALAT PEMBAKAR SAMPAH ORGANIK
}

\author{
Budhi Martana $^{1}$, Sri Sulasminingsih ${ }^{2}$, dan M. Arifudin Lukmana ${ }^{3}$ \\ Program Studi Teknik Mesin, Fakultas Teknik UPN "Veteran” Jakarta ${ }^{13}$ \\ Program Studi Teknik Industri, Fakultas Teknik UPN "Veteran”Jakarta ${ }^{2}$ \\ email ${ }^{1}$ : budhimart0605@gmail.com
}

\begin{abstract}
Garbage is a part that can not be separated from human life, garbage is an item that is wasted or discarded, and is often regarded as something that is not useful. Garbage is also a major problem, especially in big cities. Trash negative impact on the environment, because the waste can lead to environmental pollution, disruption of cleanliness, safety and health. The objectives of this study were (1) identify the state of the art paradigm of organic waste by burning, (2) designing the incinerator simple as one alternative to appropriate technology and is equipped with a system of utilization of the heat produced, (3) gives a solution to the waste problem so it is useful to reduce the waste generated in landfills while, and (4) examine the performance of the incinerator that has been designed. The method of planning the incinerator is divided into (1) the design of the product, (2) the design process, and (3) engineering design, (4) a manufacturing process or manufacture tools, and (5) testing tool. The incinerator is designed in accordance with the planning, the construction of the incinerator is made of a metal plate with a thickness of $3 \mathrm{~mm}$, the dimensions of the combustion chamber is the outer diameter of $350 \mathrm{~mm}$, an inner diameter of $290 \mathrm{~mm}$, and $410 \mathrm{~mm}$ high combustion chamber. Organic waste burner is capable of burning organic waste as much as $28 \mathrm{Kg} / \mathrm{hour}$. Garbage burning rate of $9.33 \mathrm{Kg} / \mathrm{h}$, the air discharge design results obtained at $0.0173 \mathrm{~m} 3 / \mathrm{sec}$.
\end{abstract}

Keywords: organic waste, incinerator, planning

\section{PENDAHULUAN}

Sampah merupakan bagian yang tidak dapat terpisahkan dari kehidupan manusia, sampah adalah suatu barang yang terbuang atau dibuang, dan sering dianggap sebagai sesuatu hal yang tidak berguna. Sampah juga merupakan salah satu masalah utama khususnya di kota-kota besar. Sampah berdampak negatif terhadap lingkungan, karena sampah dapat mengakibatkan pencemaran lingkungan, gangguan kebersihan, keamanan dan kesehatan.

Sampah organik adalah suatu sampah yang dapat mengalami pelapukan (dekomposisi) serta dapat terurai menjadi bahan yang lebih kecil dan tidak berbau (kompos). Kompos sendiri merupakan hasil pelapukan dari bahan-bahan organik seperti: daun-daunan, jerami, alang-alang, rumput, dan bahan lain yang sejenis yang proses pelapukannya dipercepat oleh bantuan manusia. Untuk Sampah pasar khususnya pasar tradisional seperti pasar sayur mayur, pasar buah, atau pasar ikan, dan jenisnya relatif seragam. Sekitar 95\% sampah yang berasal dari pasar-pasar tersebut berupa sampah organik sehingga lebih mudah ditangani. Sedangkan sampah yang berasal dari pemukiman atau rumah tangga sangat beragam, tetapi secara umum minimal $75 \%$ merupakan sampah organik dan sisanya anorganik. Sampah Organik yang berasal dari rumah tangga yaitu seperti sisa makanan, sayuran, daun-daun kering, dan sebagainya.

Pemanfaatan sampah dapat dilakukan dengan beberapa cara disesuaikan dengan jenis sampah yang ada. Pemusnahan sampah tersebut dapat dilakukan dengan suatu proses pembakaran. Pembakaran merupakan penanganan sampah yang dapat dilakukan, dalam proses pembakaran diperlukan alat untuk mengontrol pembakaran sehingga tidak terjadi polusi terhadap lingkungan sekitar. Alat yang digunakan untuk proses pembakaran tersebut adalah insenerator. Alat ini dapat berfungsi untuk mengontrol panas pembakaran sampah dan juga sebagai alat konversi energi panas hasil pembakaran yang dapat digunakan sebagai energi alternatif bagi proses lain.

Proses pembakaran sampah pada ruang terbuka (perkarangan rumah atau kebun) dapat menyebabkan pembakaran tidak terkontrol dan gangguan lingkungan sekitar. Kegiatan 
pembakaran sampah tersebut seringkali dilakukan oleh masyarakat karena pada umumnya merasa terganggu dengan timbulan sampah yang dihasilkan.

Salah satu solusi dalam penanganan sampah adalah dengan proses pembakaran menggunakan alat atau instalasi pembakar sampah (incinerator). Penggunaan alat pembakar sampah selain dapat mengurangi dampak negatif proses pembakaran (asap, bau, radiasi panas), juga sebagai upaya pemanfaatan energi panas hasil pembakaran sampah.

\section{Perumusan Masalah}

Perumusan masalah pada penelitian ini adalah bagaimana melakukan inovasi terhadap alat pembakar sampah yang ada sebagai salah satu alternatif teknologi tepat guna (TTG) pengolahan sampah organik, sehingga bermanfaat untuk mengurangi timbulan sampah di tempat pembuangan sampah sementara

\section{Tujuan Penelitian}

Tujuan yang ingin dicapai dari penelitian ini adalah (1) mengidentifikasikan state of the art paradigma pengolahan sampah organic dengan cara pembakaran, (2) merancang alat pembakar sampah sederhana sebagai salah satu alternatif teknologi tepat guna dan dilengkapi dengan system pemanfaatan panas yang dihasilkan, (3) memberi solusi terhadap permasalahan sampah sehingga bermanfaat untuk mengurangi timbulan sampah di tempat pembuangan sampah sementara, dan (4) menguji performa alat pembakar sampah yang telah dirancang.

\section{TINJAUAN PUSTAKA}

\section{Sampah}

Sampah adalah suatu bahan yang terbuang atau dibuang dari hasil aktivitas manusia maupun alam yang belum memiliki nilai ekonomis. Aktivitas penghasil sampah adalah perdagangan, rumah tangga, industri, pertanian, pertambangan dan energi. Sampah terdiri atas sampah dalam bentuk padatan, cairan, dan gas.

Tabel 1.

Komposisi Sampah Kota Besar di Indonesia

\begin{tabular}{lcc}
\hline No & $\begin{array}{c}\text { Jenis } \\
\text { Sampah }\end{array}$ & Prosentase \\
\hline 1. & Organik & 70,20 \\
2. & Kertas & 10,90 \\
3. & Kaca & 1,70 \\
4. & Plastik & 8,70 \\
5. & Logam & 1,80 \\
6. & Lain-lain & 6,20 \\
\hline
\end{tabular}

Sampah padatan sering menjadi masalah bagi beberapa kota besar di Indonesia. Dalam penanganan sampah tersebut kota-kota besar melakukan pengumpulan dan membuang sampah di daerah pinggiran kota. Penanganan sampah di kota besar meliputi kegiatan pengumpulan, pengangkutan, dan pembuangan akhir. Namun di beberapa daerah sampah juga dibakar secara langsung.

\section{Alat Pembakar Sampah}

Incinerator adalah alat yang digunakan untuk proses pembakaran sampah baik dalam bentuk padatan, cairan atau gas. Alat ini berfungsi untuk merubah bentuk sampah menjadi ukuran yang lebih kecil. Perubahan ukuran tersebut dapat mencapai 50-90\% dari volume sebelumnya. Selain itu alat pembakar sampah di beberapa Negara juga dijadikan sebagai pembangkit listrik dengan memanfaatkan energi yang berasal dari pembakaran sampah tersebut yang dikonversikan menjadi energi listrik.

Alat pembakar sampah (incinerator) terdiri atas 2 (dua) tipe berdasarkan metode pembakarannya, yaitu tipe kontinyu dan tipe batch. Pada alat pembakar sampah tipe kontinyu, sampah dimasukkan terus menerus dan bergerak secara kontinyu dengan melewati proses pembakaran dan pembuangan sisa pembakaran. Sedangkan tipe bacth, sampah dimasukkan hingga mencapai kapasitas dari alat pembakar terpenuhi dan mengalami proses pembakaran hingga didapat sisa pembakaran dalam satu waktu tertentu.

Pemanfaatan panas alat pembakar sampah sebagai pemanas air sebelumnya telah dilakukan oleh Budiman (2001), dengan menggunakan pipa penukar panas sepanjang $3 \mathrm{~m}$. Alat pembakar sampah tersebut menghasilkan panas yang dapat digunakan untuk keperluan rumaah tangga. Alat pembakar sampah yang dirancang Budiman (2001) juga dilengkapi dengan ruang pengendapan zat padat. Namun ruangan tersebut belum dimanfaatkan untuk efisiensi thermal sistem insenerator. Memiliki fungsi untuk membakar sampah sehingga syarat-syarat insenerator mampu membakar sampah secara sempurna dan habis serta dapat meminimalisir dampak negatif terhadap lingkungan.

Alat pembakar sampah dalam pengoperasiannya dapat menghasilkan temperature sebesar $815^{\circ} \mathrm{C}$ hingga $1.095^{\circ} \mathrm{C}$ (Pichtel, 2005). Pada perancangan insenerator perlu dipertimbangkan jumlah udara yang diperlukan untuk pembakaran, system pembakaran awal, jumlah sampah yang dibakar, serta bagaimana pengelolaan asap yang dihasilkan 
oleh pembakaran sehingga tidak mencemari lingkungan.

\section{Konsep Perancangan Teknik}

Perancangan adalah bagian dari kegiatan rekayasa yang merupakan usaha secara intelektual untuk memenuhi tuntutan-tuntutan tertentu dengan cara sebaik mungkin. Sedangkan pengertian rekayasa adalah penerapan ilmu dan matematik untuk memanfaatkan benda dan energi dalam alam ini, sehingga berguna bagi manusia dalam kegiatan pembuatan bangunan, permesinan, produk, sistem, dan proses (Bagiasna, K., 1992).

Secara konseptual kegiatan perancangan dapat dibedakan menjadi (1) perancangan produk, (2) perancangan proses, dan (3) perancangan rekayasa (engineering design).

Ciri-ciri perancangan meliputi (1) merupakan kegiatan kreatif yang dilandasi oleh pemahaman yang baik atas bidang-bidang keilmuan tertentu serta pengetahuan dan pengalaman praktis bidang khusus, (2) merupakan optimasi atas tujuan tertentu dalam berbagai kendala yang ada bahkan saling bertentangan, dan (3) memuat tahapan-tahapan sebagai berikut, (a) ide dan kejelasan tugas, (b) rancangan konseptual, (c) rancangan bentuk dan tata letak, (d) rancangan detail, (e) pembuatan prototipe/model, dan (f) pengujian.

Urutan tahapan tersebut merupakan kegiatan sistematis dan terstruktur, dimana tahapan yang sedang dibahas selalu berguna untuk memberikan umpan balik bagi perbaikan tahapan sebelumnya. Semua tahapan tadi dinilai dengan tolok ukur berdasarkan kriteria kefungsian (kriteria teknik) dan kriteria efisiensi (kriteria ekonomi).

Perancangan alat pembakar sampah dilakukan atas dasar pertimbangan dan masukan, analisis awal dan dilengkapi dengan perhitungan teoritis. Bentuk pembakar sampah padat dapat berupa kotak atau silinder, berdasarkan teori perpindahan panas diharapkan bahwa bentuk silinder lebih baik untuk ruang bakar, karena distribusi panas di dalam ruang bakar akan lebih merata.

Jika suhu maksimum berada di pusat silinder atau sumber kalor ada di pusat silinder maka laju perpindahan kalor (Q) dari tengah ke luar silinder seperti dinyatakan dalam persamaan berikut.

$$
\begin{aligned}
& Q=U_{0} A_{0}\left(T_{1}-T_{0}\right) \\
& \text { dengan, } \\
& 1 \\
& U_{0}=
\end{aligned}
$$

Dimana:
$\mathrm{A}_{\mathrm{o}}=2 \pi \mathrm{r}_{0} \mathrm{~L}$, luas permukaan perpindahan kalor $\left(\mathrm{m}^{2}\right)$

$\mathrm{r}_{\mathrm{o}}=$ jari-jari luar $(\mathrm{m})$

$\mathrm{r}_{1}=$ jari-jari dalam $(\mathrm{m})$

$\mathrm{h}=$ koefisien perpindahan kalor konveksi $\left(\mathrm{W} / \mathrm{m}^{2}\right.$

$\mathrm{K})$

$\mathrm{k}=$ koefisien perpindahan kalor konduksi $\left(\mathrm{W} / \mathrm{m}^{2}\right.$

$\mathrm{K})$

$\mathrm{T}_{\mathrm{o}}$ = suhu dinding tungku luar $\left({ }^{\circ} \mathrm{K}\right)$

$\mathrm{T}_{1}=$ suhu maksimum dinding tungku dalam $\left({ }^{\circ} \mathrm{K}\right)$

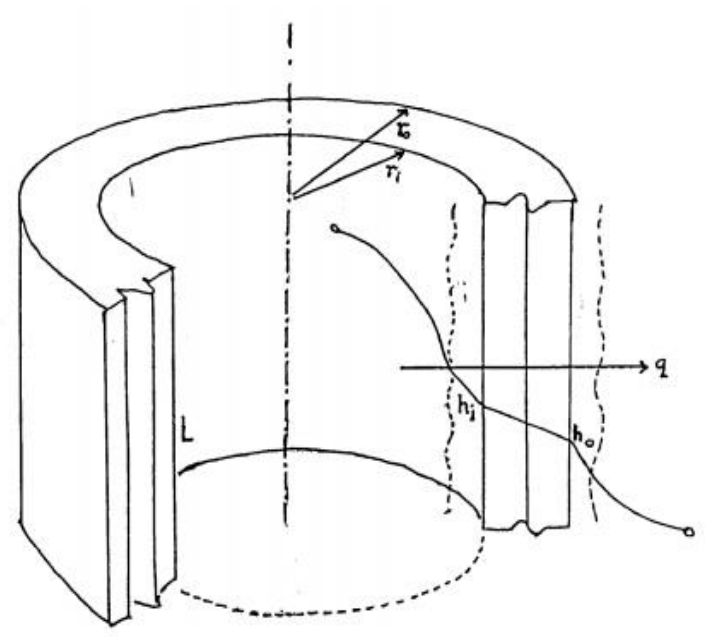

Gambar 1. Perpindahan Kalor Dalam Ruang Berbentuk Silinder

Bentuk silinder juga mempunyai pengaruh yang baik bagi pengendalian radiasi yang dipancarkan sampah. Ruang bakar merupakan jantung pembakar sampah, yang di dalamnya dapat berlangsung reaksi pembakaran sempurna pada suhu yang tinggi, tergantung jenis material sampah yang dibakar. Untuk mencapai suhu pembakaran sempurna tersebut mula-mula dilakukan proses pengeringan sampah dengan memberi sejumlah kalor untuk penguapan sampah basah dan penguapan kandungan air dalam sampah, sehingga dicapai suhu sampah kering. Kemudian ditambahkan kalor untuk menaikkan suhu sampai mencapai titik didih air. Selanjutnya ditambahkan lagi kalor untuk menaikkan suhu dan titik didih sampai mencapai titik nyala. Titik nyala ini tergantung dari jenis material sampah yang dibakar.

\section{Pembakaran Biomassa}

Pembakaran adalah proses bereaksinya bahan bakar (biomassa, minyak, dll) dengan oksigen. Reaksi pembakaran secara umum terjadi melalui 2 (dua) cara, yaitu pembakaran sempurna dan pembakaran habis. Pembakaran sempurna adalah proses pembakaran yang terjadi jika semua 
$\mathrm{CO}_{2}$, sedangkan pembakaran habis adalah proses pembakaran yang terjadi jika bahan bakar terbakar habis tetapi oksigen yang diperlukan untuk pembakaran tidak semuanya menjadi $\mathrm{CO}_{2}$. (Abdullah, dkk, 1998).

Pembakaran kayu dalam kiln tertutup dapat mengakibatkan kayu terdekomposisi menjadi fluida dan zat padat (Satonaka dalam Smith, 1982). Pada proses pembakaran kayu, proses pirolisis mulai dihasilkan $\mathrm{CO}_{2}$ dan $\mathrm{CO}$, jumlahnya akan terus naik hingga mencapai maksimal yaitu pada suhu $400^{\circ} \mathrm{C}$. Pada suhu $400^{\circ} \mathrm{C}$ juga dihasilkan sedikit ter serta banyak menghasilkan gas (17\%) dan arang/abu (34\%). Pada suhu $700^{\circ} \mathrm{C}$ dihasilkan gas hidrogen dan metan, kemudian pada suhu lebih dari $800^{\circ} \mathrm{C}$ volume gas yang dihasilkan meningkat sedangkan berat arang/abu menurun.

Pembakaran sampah secara sempurna dipengaruhi oleh jumlah udara yang dibutuhkan untuk proses pembakaran dalam insenerator (Hadiwiyoto, 1983). Jumlah udara yang dibutuhkan dapat didekati melalui perbandingan kebutuhan udara dan bahan (sampah) dalam reaksi pembakaran biomassa melalui pendekatan kandungan karbon dan hydrogen dalam bahan bakar.

Menurut Abdulah, dkk (1998) reaksi pembakaran biomassa secara umum adalah sebagai berikut:

$$
\mathrm{CH}_{1.4} \mathrm{O}_{0.6}+1.05 \mathrm{O}_{0.2} \longrightarrow \mathrm{CO}_{2}+1.4 \mathrm{H}_{2} \mathrm{O}
$$

Kebutuhan oksigen $\left(\mathrm{O}_{2}\right)$ untuk proses pembakaran dipengaruhi oleh prosentase kandungan karbon dan hydrogen dalam bahan bakar. Volume $\mathrm{O}_{2}$ yang dibutuhkan untuk pembakaran $1 \mathrm{Kg}$ karbon adalah $1.96 \mathrm{~m}^{3}$ sedangkan kebutuhan $\mathrm{O}_{2}$ untuk pembakaran $1 \mathrm{Kg}$ hydrogen adalah $5.85 \mathrm{~m}^{3}$ (Perry dan Chilton, 1973). Dalam proses pembakaran, oksigen biasanya didapat dari udara bebas, oksigen yang terkandung dalam udara adalah 21\% dari total udara bebas (Anshory, 1988). Kebutuhan udara minimum untuk proses pembakaran dapat dicari menggunakan persamaan berikut.

$$
W_{\text {min }}=\stackrel{100}{21} \text {----- } x[(1.96 \times C)+(5.85 \times \text { H })]
$$

Dimana:

$\mathrm{W}_{\text {min }}=$ Kebutuhan udara minimum $\left(\mathrm{m}^{3} / \mathrm{kg}\right.$ bahan bakar)

$\mathrm{C}=$ Kandungan karbon dalam bahan bakar (\%)

$\mathrm{H}=$ Kandungan hydrogen dalam bahan bakar (\%)
Laju pembakaran $\left(\mathrm{B}_{\mathrm{bt}}\right)$ dapat dicari melalui perbandingan bobot bahan yang akan dibakar (m) dengan waktu pembakaran (t)

$$
B_{b t}=\mathbf{m} / \mathbf{t}
$$

Dimana:

$\mathrm{B}_{\mathrm{bt}}=$ Laju pembakaran ( $\left.\mathrm{kg} / \mathrm{jam}\right)$

$\mathrm{m}=$ Bobot bahan bakar / sampah (kg)

$\mathrm{t}=$ Waktu pembakaran (jam)

Debit udara yang dibutuhkan untuk pembakaran dapat dicari dengan mengalikan jumlah kebutuhan udara minimum dengan laju pembakaran.

Dimana:

$$
\mathbf{Q}_{\mathbf{u d}}=\mathbf{W}_{\min } \mathbf{B}_{\mathbf{b t}}
$$

$\mathrm{Q}_{\mathrm{ud}}=$ Debit udara $\left(\mathrm{m}^{3} / \mathrm{jam}\right)$

$\mathrm{W}_{\text {min }}=$ Kebutuhan udara minimum $\left(\mathrm{m}^{3} / \mathrm{kg}\right.$ bahan bakar)

$\mathrm{B}_{\mathrm{bt}}=$ Laju pembakaran (kg/jam)

Menurut Abdullah, dkk, (1998) debit udara pada proses perancangan untuk pembakaran perlu ditambahkan exxes udara (Air Exxes) sebesar $40 \%$ dari total debit udara yang dibutuhkan secara teoritis.

Dimana:

$$
Q=\left(40 \% \times Q_{u d}\right)+Q_{u d}
$$

$\mathrm{Q}=$ Debit udara perancangan ( $\mathrm{m}^{3} /$ detik)

\section{Pengertian Perpindahan Panas}

Perpindahan panas (heat transfer) ialah ilmu untuk meramalkan perpindahan energi yang terjadi karena adanya perbedaan suhu diantara benda atau material. Teori perpindahan panas tidak hanya mencoba menjelaskan bagaimana energi kalor itu berpindah dari satu benda ke benda lainya, tetapi juga dapat meramalkan laju perpindahan yang terjadi pada kondisi-kondisi tertentu.

Ilmu perpindahan panas melengkapi hukum pertama dan kedua thermodinamika, yaitu dengan memberikan beberapa kaidah percobaan merupakan suatu metode yang dapat dimanfaatkan untuk menentukan perpindahan energi yang terjadi pada suatu benda yang dalam sistem operasinya sangat berhubungan dengan teori perpindahan panas. Sebagaimana juga dalam ilmu termodinamika, kaidah-kaidah percobaan ini digunakan dalam masalah perpindahan kalor cukup sederhana, dan dapat dengan mudah dikembangkan sehingga dapat mencakup berbagai ragam situasi praktis.

Dalam perpindahan panas pada umumnya dikenal tiga cara perpindahan panas yang memiliki mekanisme yang berbeda satu dengan yang lainnya, yaitu secara konduksi, 


\section{Perpindahan Panas Konduksi}

Konduksi adalah proses perpindahan panas yang terjadi akibat adanya perpindahan energi yang terjadi karena hubungan molekul secara langsung tanpa adanya perpindahan molekul yang cukup besar di dalam satu medium padat.
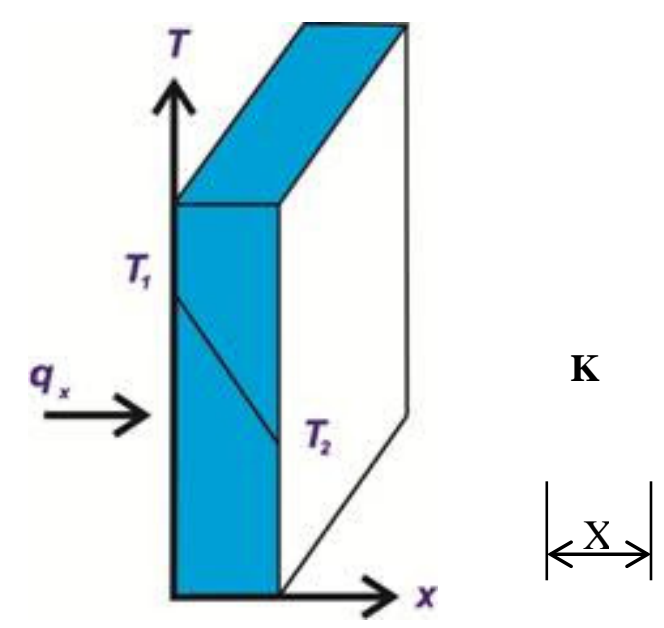

Gambar 2. Proses Laju Perpindahn Panas

\section{Konduksi}

Jika pada suatu benda terdapat gradient suhu (temperature gradient), maka akan terjadi perpindahan dari bagian yang bersuhu tinggi ke bagian yang bersuhu lebih rendah. Maka dikatakan bahwa energi berpindah secara konduksi dan bahwa laju perpindahan panas tersebut berbanding dengan gradient suhu normal. Jika dimasukkan konstanta proporsionalitas (proportionality constant) atau tetapan kesebandingan untuk menentukan besarnya laju perpindahan panas $(q \mathrm{k})$ secara konduksi maka rumus sebagai berikut:

$$
q \mathrm{k}=-\mathrm{KA} \frac{\mathrm{dT}}{\mathrm{dx}}
$$

Dimana:

$q$ : Laju perpindahan panas (W)

$\mathrm{k}$ : Koefisien konduktifitas thermal dari benda yang dilalui panas $\left(\mathrm{W} / \mathrm{m} .{ }^{\circ} \mathrm{C}\right)$

A : Luas permukaan pengantar panas $\left(\mathrm{m}^{2}\right)$

$\frac{\mathrm{dT}}{\mathrm{dx}}$ : Gradien suhu ke arah perpindahan panas $\left({ }^{\circ} \mathrm{C} / \mathrm{m}\right)$

Persamaan di atas merupakan persamaan dasar dari konduktifitas thermal. Dengan menggunakan persamaan dasar tersebut, maka akan dapat ditentukan besarnya perpindahan kalor dan arah aliran kalor dalam zat padat.

Jika sistem berada pada keadaan tunak (steady state), yaitu bila suhu tidak berubah menurut waktu, pemecahannya hanya perlu melaksanakan integrasi dari persamaan di atas, dan dengan mensubtitusikan nilai-nilai untuk memecahkan persoalannya.

Sifat yang paling mencirikan logam adalah konduktifitas termal dan konduktifitas listriknya yang tinggi. Umumnya logam adalah konduktor kalor yang lebih baik dari material non-logam dan juga material isolator. Pada proses perpindahan panas konduksi, nilai konduksifitas thermal sangat berperan penting dalam perubahan temperatur yang terjadi akibat peroses perpindahan panas tesebut.

Konduktifitas thermal adalah suatu besaran intenfis bahan yang menunjukan kemampuannya untuk mengantarkan panas (kalor). Dalam beberapa contoh bahan yang mendapat perlakuan panas dari suatu sumber panas, dapat diketahui bahwa bahan tersebut akan terlibat dalam proses laju kalor, yang dipengaruhi oleh nilai konduktifitas thermal dari bahan yang menunjukan seberapa cepat kalor mengalir dalam bahan tersebut.

\section{Perpindahan Panas Konveksi}

Perpindahan panas secara konvesi adalah proses transfer energi yang merupakan gabungan dari konduksi kalor yang menyimpan energi dan gerakan fluida yang bersifat mencampurkan partikel-partikel fluida. Konveksi merupakan mekanisme perpindahan energi antara permukaan benda padat dan cairan atau gas. Perpindahan energi dengan cara konveksi dari suatu permukaan yang bersuhu lebih tinggi dibandingkan suhu fluida disekitarnya berlangsung dalam beberapa tahap. Pertama, panas akan mengalir dengan cara konduksi dari permukaan partikel-partikel fluida yang berbatasan. Energi yang berpindah dengan cara yang demikian akan menaikan suhu dan energi dalam partikel-partikel fluida ini. Kemudian partikel-partikel fluida tersebut akan bergerak ke daerah yang bersuhu lebih rendah didalam fluida dan bercampur serta memindahkan sebagian energinya kepada partikel-partikel fluida lainnya.

Laju perpindahan panas secara konveksi dihubungkan dengan beda suhu menyeluruh anatara dinding dan fluida, dan luas permukaan. Perindahan panas konveksi dapat diklasifikasikan menjadi 2 yaitu konveksi bebas (free convection) dan konveksi paksa (forced convection).

\section{Perpindahan Panas Radiasi}

Perpindahan panas secara radiasi dipancarkan oleh suatu benda dalam bentuk batch, energi yang berbatas atau quanta. Gerakan panas radiasi di dalam ruang mirip perambatan cahaya dan dapat diuraikan dengan teori gelombang. Perpindahan panas dengan cara radiasi meniadi 
sangat penting dengan meningkatnya suhu suatu benda. Jumlah energi yang meninggalkan suatu permukaan sebagai panas radiasi tergantung pada panas mutlak dari sifat permukaan tersebut. Radiator sempurna atau benda hitam (block body) memancarkan energi radiasi dari permukaannya dengan laju perpindahan panas (Qr) yang berkaitan dengan persamaan :

$$
\mathbf{Q r}=\sigma . \mathbf{A} . \mathbf{T}^{4}
$$

Dimana :

Qr : Laju perpindahan panas (W)

$\sigma$ : Konstanta Stefan - Boltzman $\left(\mathrm{W} / \mathrm{m}^{2} .{ }^{\circ} \mathrm{C}^{4}\right)$

A : Luas penampang permukaan $\left(\mathrm{m}^{2}\right)$

$\mathrm{T}$ : Temperatur permukaan $\left({ }^{\circ} \mathrm{C}\right)$

\section{METODOLOGI PENELITIAN}

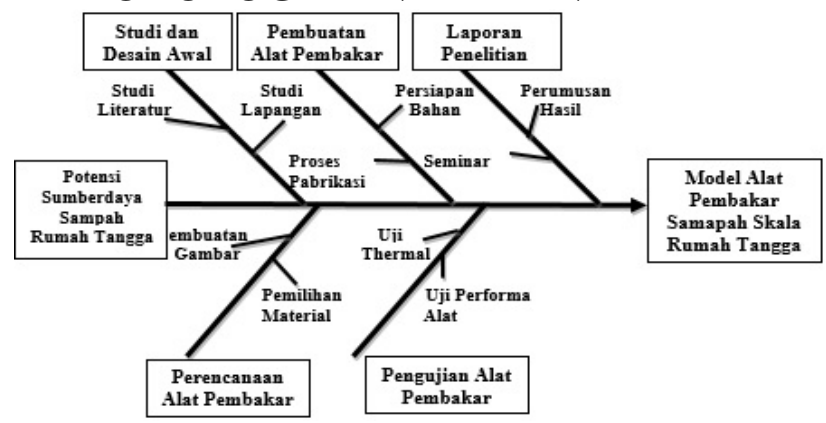

Gambar 3. Fishbone Diagram Proses

Perancangan Alat Pembakar Sampah Organik

\section{HASIL DAN PEMBAHASAN \\ Pendekatan Perencanaan}

Alat pembakar sampah yang direncanakan dalam bentuk silinder, dengan dilapisi batu tahan api. Pada prinsipnya alat pembakar sampah ini terdiri atas ruang pembakaran bentuk silinder, pemantik awal api, ruang pengendapan bahan padat, cerobong, lubang pemasukan udara.

Ruang pembakaran adalah ruangan dimana terjadinya proses pembakaran sampah, pemantik api berfungsi sebagai tempat penyulut awal dan membantu proses pembakaran, ruang pengendapan bahan padat berfungsi sebagai tempat penampungan bahan padat (abu) hasil pembakaran. Cerobong asap berfungsi sebagai tempat pengeluaran asap hasil pembakaran, lubang pemasukan udara berfungsi sebagai tempat masuknya udara yang dibutuhkan dalam proses pembakaran.

\section{Perencanaan Konstruksi Alat Pembakar Sampah}

Kapasitas sampah pada ruang pembakaran pada alat pembakar sampah ini ditentukan berdasarkan diameter $=290 \mathrm{~mm}$ dan tinggi $=360$ $\mathrm{mm}$ dari alat pembakar sampah yang direncanakan.

$$
\begin{aligned}
\mathbf{V} & =\boldsymbol{\pi} \mathbf{r}^{2} \mathbf{t} \\
& =\pi(145 \mathrm{~mm})^{2} \times 360 \mathrm{~mm}
\end{aligned}
$$

$$
\begin{aligned}
& =27.766 .660 \mathrm{~mm}^{3} \\
& =0,028 \mathrm{~m}^{3} \\
& =28 \mathrm{Kg}
\end{aligned}
$$

Diperoleh kapasitas sampah yang dapat dibakar kurang lebih $28 \mathrm{Kg}$.

Berat sampah $(\mathrm{m})=28 \mathrm{Kg}$, waktu pembakaran yang dibutuhkan $(\mathrm{t})=3$ Jam, kandungan karbon dalam bahan bakar (C) = 39,2\% (0,392), kandungan hidrogen dalam bahan bakar $(\mathrm{H})=4 \%(0,04)$, dan kecepatan rata-rata udara bebas disekitar lokasi pembakaran $=1$ $\mathrm{m} /$ detik.

\section{Kebutuhan udara minimum}

$$
\begin{aligned}
& \mathrm{W}_{\min }=\frac{100}{21} \\
& \mathrm{~W}_{\min }= \\
& \begin{array}{l}
100 \\
21
\end{array}
\end{aligned}
$$

$0,04)]$

$$
\mathrm{W}_{\min }=4,78 \mathrm{~m}^{3} / \mathrm{Kg}
$$

\section{Laju pembakaran yang diinginkan}

$$
\begin{aligned}
\mathrm{B}_{\mathrm{bt}} & =\mathrm{m} / \mathrm{t} \\
& =28 / 3=9,33 \mathrm{Kg} / \mathrm{jam}
\end{aligned}
$$

Debit udara secara teoritis

$$
\begin{aligned}
\mathrm{Q}_{\mathrm{ud}} & =\mathrm{W}_{\min } \times \mathrm{B}_{\mathrm{bt}} \\
& =4,78 \times 9,33=44,60 \mathrm{~m}^{3} / \mathrm{jam}
\end{aligned}
$$

Debit udara perancangan

$$
\begin{aligned}
\mathrm{Q} & =\left(40 \% \times \mathrm{Q}_{\mathrm{ud}}\right)+\mathrm{Q}_{\mathrm{ud}} \\
& =(0,4 \times 44,60)+44,60 \\
& =62,44 \mathrm{~m}^{3} / \mathrm{jam}=0,0173 \mathrm{~m}^{3} / \text { detik }
\end{aligned}
$$

\section{Pembahasan}

Alat pembakar sampah ini dirancang sesuai dengan perencanaan, konstruksi alat pembakar sampah ini terbuat dari bahan pelat besi dengan ketebalan $3 \mathrm{~mm}$, dimensi ruang pembakaran adalah dengan diameter luar $350 \mathrm{~mm}$, diameter dalam $290 \mathrm{~mm}$, dan tinggi ruang pembakaran 410 $\mathrm{mm}$. Alat pembakar sampah organik ini mampu membakar sampah organik sebanyak $28 \mathrm{Kg} / \mathrm{jam}$.

Alat pembakar ini menggunakan bahan bakar menggunakan pompa kompor semawar guna memperoleh udara dengan tekanan tertentu yang diperlukan sebagai penunjang proses pembakaran dalam ruang bakar. Sampah yang dibakar berupa sampah organik dan hasil pembakaran berupa abu secara otomatis jatuh ke bak penampungan yang diletakkan dibagian bawah ruang pembakaran.

Alat pembakar sampah organik ini memiliki beberapa komponen utama, yaitu ruang pembakaran, kompor pembakar, saringan, 
cerobong asap, dan bak penampungan abu hasil pembakaran.

Alat pembakar sampah organik ini diharapkan dapat dipergunakan sebagai sarana untuk mengurangi timbulan sampah pada sumber sampah, dapat dapat dimanfaat sebagai media pengelolaan sampah berbasis masyarakat mulai dari rumah tangga.

\section{SIMPULAN DAN SARAN Simpulan}

Alat pembakar sampah organik merupakan alat yang berguna untuk mengontrol proses pembakar sampah sehingga gangguan yang ditimbulkan dari proses pembakaran sampah dapat diminimalkan, dan energi panas yang dihasilkan dapat dimanfaatkan secara optimal.

Alat pembakar sampah ini terbuat dari bahan pelat besi dengan ketebalan $3 \mathrm{~mm}$, dan memiliki dimensi ruang pembakaran adalah dengan diameter luar $350 \mathrm{~mm}$, diameter dalam $290 \mathrm{~mm}$, dan tinggi ruang pembakaran $410 \mathrm{~mm}$.

Alat pembakar sampah organik ini mampu membakar sampah organik sebanyak $28 \mathrm{Kg} / \mathrm{jam}$.

Laju pembakaran sampah sebesar 9,33 $\mathrm{Kg} / \mathrm{jam}$, debit udara pada hasil perancangan diperoleh sebesar $0,0173 \mathrm{~m}^{3} /$ detik.

\section{Saran}

Hasil perencanaan alat pembakar sampah organik ini.diharapkan dapat dipergunakan sebagai sarana untuk mengurangi timbulan sampah pada sumber sampah, dapat dapat dimanfaat sebagai media pengelolaan sampah berbasis masyarakat mulai dari rumah tangga.

Hasil pembakaran beruapa abu dan asap/uap yang dihasilkan dari proses pembakaran sampah organik nantinya dapat dilanjutkan untuk pengkajian selanjutnya dan menjadi bahan penelitian berikutnya yang dapat dimanfaatkan oleh para peneliti.

\section{DAFTAR PUSTAKA}

Abdullah, dkk, 1998, Energi dan Listrik Pertanian, JICA, Bogor.
Bolg, Mechanical, 2013, Nilai Kalori Bahan Bakar, (Online) (http://yefrichan.wordpress.com/2013/12/ 02/nilai-kalori-bahan-bakar/)

Budiman Arif. 2001. Modifikasi Desain dan Uji Unjuk Kerja Alat Pembakar Sampah (Incinerator) Tipe Batch. Skripsi. Jurusan Teknik Pertanian, Fakultas Teknologi Pertanian, IPB.

Hadiwiyoto, S., 1983, Penanganan dan Pemanfaatan Sampah, Yayasan Idayu, Jakarta.

Harahap, Gandhi, 1999, Perancangan Teknik Mesin, Penerbit: Erlangga, Jakarta.

Holman, J.P., (Terjemahan: E. Jasjfi), 1984, Perpindahan Kalor, Penerbit: Erlangga, Jakarta.

L. Singer, Ferdinand, dan Andrew Pytel, 1995, Kekuatan Bahan, Penerbit: Erlangga, Jakarta.

Pichel John. 2005. Waste Management Practices Municipal, Hazardous, and Industries.CRC Press. New York

Pradiko, Aziz, 2014, Perancangan Konstruksi Mesin Pengupas Buah Kenari Kapasitas 5 kg/jam, (Skripsi) Teknik Mesin, Universitas Nasional, Jakarta.

Pranomo, S., 2009, Incenarator Sederhana, (Online), (http://www.magelangkab.go.id/ dinkes/new//document/)

Sani, Rasio Ridho. 2014. Deklarasi Menuju Indonesia Bersih Sampah 2020 seKalimantan. Diunduh dari http://www.menlh.go.id/deklarasimenuju-indonesia-bersih-sampah-2020se-kalimantan/. Diakses tanggal 23 April 2015.

Sutjita, Deddy, 2010, Perancangan Konstruksi Rangka Alat Uji Tekan Material Polimer Kapasitas $6 \mathrm{~kg}$ Menggunakan Lasan, (Skripsi) Teknik Mesin, Universitas Nasional, Jakarta.

Zainuri, Ach. Muhib, 2008, Kekuatan Bahan, Penerbit: Andi Offset, Yogyakarta. 